\title{
Issue of Fiscal Federalism and National Development in Nigeria during Obasanjo Administration
}

\author{
Okeke, Martin Ifeanyi ${ }^{1}$ \\ Eme Okechukwu Innocent ${ }^{2}$ \\ Dept of Political Science Nnamdi Azikiwe University, Awka-Nigeria ${ }^{1}$ \\ Dept of Public Administration \&Local Government University of Nigeria, Nsukka-Nigeria ${ }^{2}$
}

\section{Doi:10.5901/jesr.2013.v3n10p109}

\begin{abstract}
Nigeria operates a fiscal arrangement that caters for the needs of component states. Federalism is characterized by extensive inter-governmental relations in which federal, state and local tier interact to seek policies and programmes that will cater for the welfare of the public. This can become a reality when there is financial insubordination from any levels of government. It implies that federal, state or local level should depend on one another in performing their statutory functions in a federal state. The challenges of fiscal relations and national development is enormous in Nigeria, the paper will $x$-ray issues within the ecology of Nigerian federal structure, ranging from revenue sharing to fiscal decentralization, allocation expenditure and tax-raising power among the three levels of government. The paper concludes that the prospect of any nation depend on proper arrangement rooted in equity, fairness and justice to enhance equitable revenue formula for the best interest of Nigerian state.
\end{abstract}

Keywords: Tax, Allocation, Fiscal relations, national development, Revenue

\section{Introduction}

The issue of fiscal federalism in Nigeria seems to have derailed national development due to fiscal imbalance, over-dependence on the centre, agitation for resource control, among others. Thus, inequitable revenue sharing practices have not addressed the problem of true federalism. Fiscal Federalism is a political-economic arrangement whereby the public revenue of a federation is shared among the various levels of government. These levels are centre, the federating states or provinces and the applicable regional governments (Uchendu, 2001). Fiscal federalism necessitates revenue sharing arrangement to enable the component units carry out their various functions (Danjuma, 1994). Federalism recognizes two or three levels of government (central, state and local), each level has different expenditure responsibilities and taxation powers for national development (Buettner and Wildasin, 2007). The issue of revenue sharing formula generated intense debate that led to the demand for sovereign national conference in Nigeria, but the revenue resources have not tallied with constitutional responsibilities (Onuoha, 2007). Put differently, financial subordination makes mockery of federalism no matter how carefully the legal forms may be preserved. The states must not permanently remain dependent on the federal government for allocations. The degree of fiscal decentralization in a federal state contributes to national development, employment generations and poverty alleviation (Owolabi, 2011). The paper reviewed some extant literature on Fiscal federalism, national development, evolution of fiscal federalism and Challenging issue affecting fiscal federalism and national development during Obasanjo Administration. 


\section{Problem statement}

Fiscal federalism is the dynamic interaction between different tiers of government. It poses questions as to how the nature of financial relations in any federal system affects the distribution of the nation's wealth. Nigeria is beset with structural imbalance, and true federalism implies that component units should freely pursue their own development.

Revenue sharing in Nigeria, has witnessed a plethora of reviews, as evidenced by various committees and commissions instituted in this regard, yet no reliable formula has been evolved in meeting the country's yearnings and aspirations (Teidi, 2003:39). Such experienced deficiencies have triggered off many untoward actions, particularly among the sub-national governments that complain of fiscal imbalance (Okeke, 2004:28). The statutory allocations from the Federation Account, even when it is disbursed, result into zero allocation for some of the federating units to run their affairs (Yusuf, 2008:1). Disharmonious fiscal federalism reflects on low level of political maturity and inability to allow true federalism to evolve without undue politicization. Nigerian federalism is fraught with the external imposition of arrangement and political will, amongst others.

Revenue allocation among various units of government in Nigeria is replete with agitations, controversies and outright rejections due to the nature of politics in vogue. Sec. 149 (7) of the 1979 Constitution provides for state-local government fiscal relations, while Section 162 (5) of the 1999 Constitution regards local government as an extension of the state tier, this leads to disharmonious fiscal federalism. The 1977 Aboyade Technical Committee on population was illogical as the principle of national interest it recommended defied particular interpretation in the prevailing circumstances in Nigeria. Moreover, the 2005 Political Reform Conference was stalemated because; delegates from South-South Region staged a walk out on the issue of fiscal imbalance. Financial relations of the component units of any federation should bring about federal progress and productivity. In Nigerian federation however, it appears as if fiscal federalism brings disharmony among the federating units, and this reduces the productive capacity of the federation as an entity.

\section{Clarification of Concept}

\subsection{Fiscal Federalism}

Federalism is an institutional arrangement aimed at addressing governmental problems that bothers on maintaining unity while at the same time preserving diversity. This implies that each tier of government is coordinate in its sphere of authority and should have appropriate taxing powers to exploit its independent sources of revenue (Vincent, 2001:42). If state authorities, find that the services allotted them are too expensive for them to perform, and if they call on federal authorities for grants and subsidies to assist them, they are no longer coordinate with the federal government but subordinate to it. Financial subordination makes an end of federalism in fact, no matter how carefully the legal forms may be preserved. It follows that both state and federal authorities in a federation must be given the power in the constitution have access to control its own financial resources. Each must have a power to tax and to borrow for the financing of its own services by itself. Sagay (2008:11) states that federalism is an arrangement whereby powers within a country are shared between central and component units in such a way that each unit operates directly within their jurisdiction. The cardinal principle of federalism is that no level of government is subordinate to another, though there must be central government for this exercise. Tekun (2000:13) states that fiscal federalism is the form of government where the component units of a political organization participate in sharing powers and functions in a co operative manner through the combined forces of ethnic pluralism and cultural diversity. Musgrave (1959) and Oates (1972) state that fiscal federalism concern the division of public sector functions and finances in a logical way among multiple layers of government. Musgrave (1959) and Oates (1972) opined that the 
finances and functions of government should be shared in a manner that is acceptable by all involved. Fiscal federalism is the allocation of tax powers and expenditure responsibilities between various levels of government. Tella (2000) posits that Nigerian fiscal federalism structure involves the allocation of expenditure and tax raising power among federal, state and local governments. Nyong (1999), states that fiscal federalist is the relations among various levels of government in respect to allocation of national revenue and tax powers to the constituent units in a federation. He asserts that the principle of fiscal federalism is anchored on revenue sharing (vertical) and distribution of revenue (horizontal) among various tiers of government. Ekpo (2003), states that fiscal federalism refers to the allocation of resources among tiers of government to discharge the responsibilities assigned within their jurisdiction. Mobolaji (2002) supports the views of Akindele and Tella (1996), when he opined that in a federal state, each unit should have its own sphere of responsibilities, and each should be blamed or commended on how it functions within its own sphere. The former governor of Akwa-Ibom state Chief Victor Attah acknowledged the view of Mobolaji when he states that the 1999 Constitution constitutes a fundamental aberration and a violation of our association as Nigerians. He states that the founding fathers of Nigeria agreed on the basis of the foundation in Nigeria as a true federal state, including fiscal federalism but this has been purportedly marred by the Obasanjo administration. Fiscal Federalism refers to the fiscal arrangement among the different tiers of government in a federal structure (Ekpo, 2003). Uche (2004), states that fiscal federalism is the criterion for government to share revenue among various tiers of government. Ofuebe (2005) indicates that these revenues have fixed principles; and this heightened its inclusion in section 162(2) of the 1999 Constitution of Nigeria.

\subsection{National Development}

Development as a concept is a victim of definitional pluralism; attempts have been made by scholars to conceptualize national development. Some of these definitions will be explored for the purpose of this study. Wood hall (1985) defined national development as the improvement of a country's productive capacity through changes in social attitude, values and behaviour and finally, changes toward social and political equality and eradication of poverty. Tolu and Abe (2011) refers national development as a phenomenon that embraces a whole nation, it is the overall development or a collective socio-economic, political as well as religious advancement of a nation. This is best achieved through development planning, which can be described as the country's collection of strategies mapped out by the government. National development is the ability of a county or countries to improve the social welfare of the people by providing social amenities like quality education, potable water, transportation infrastructure, medical care (Wikipedia, 2010). Gboyega (2003) captures national development as an idea that embodies all attempts to improve the conditions of human existence in all ramifications. It implies improvement in material well being of all citizens, not the most powerful and rich alone, in a sustainable way such that today's consumption does not imperil the future, it also demands that poverty and inequality of access to the good things are drastically reduced. It seeks to improve personal physical security and livelihoods and expansion of life chances. Naomi (1995) believes that national development involve not only economic growth, but some notion of equitable distribution, provision of health care, education, housing and other essential services all with a view to improve the individual and collective quality of life. Chrisman (1984) describe national development as the capacity of political systems to initiate and domesticate positive changes, including meeting basic needs, democratization and social justice as well as becoming increasingly less dependent on international capitalism. National development is not only an economic exercise, but involves both socioeconomic and political issues and pervades all aspects of societal life. 


\section{Evolution of Fiscal Federalism in Nigeria}

Federalism as practiced in Nigeria today is a far cry from what true federalism represents. As the nation awakens to the realities of its ethnic, religious, political diversities and corporate existence, the structure of her federalist claims has to be revisited and refocused. True federalism in the real sense of the word promotes accelerated economic development, it unifies and binds people together, and this triggers intellectual dialogue and provokes a healthy rivalry in revenue generation. These laudable goals are only achieved where the federating units are given free access in decision making and inputs into governance. Federalism, as practiced in Nigeria today is linked to a lion chasing an antelope and squeezing out life from it (the lion represent the federal government while the antelope represents the states government). The federal structure of Nigeria today is a gross anomaly, this present structure has positioned itself as an octopus firmly gripping the federating units with its poisonous clutch and constantly dictating its destiny (Denial, 2002). The evolution of Nigeria's fiscal federalism emanated from historical, economic, political, constitutional, social and cultural factors. In view of this, fiscal federalism has been a central feature of intergovernmental relations in Nigeria, The construction of stable and acceptable revenue formula has been the subject of many commissions and committees since 1914 (Ekpo, 2003). Fiscal federalism in Nigeria has its legal basis laid in the constitution. The 1999 constitution contains copious citations in the second and fourth schedule on the tax powers of the federal, state and local government and also on the system of revenue allocation and management of public funds in Nigeria. The details of these are contained in section 162-168, item 59 (part 1), items A $1 a, b$ and 2 (part II) D7-10 in the second schedule, item $32 a-c$ in the $3^{\text {rd }}$ schedule and item, $1 \mathrm{~b}$, section 7 of the $4^{\text {th }}$ schedule.

Pre-independence Period: The process of federal structure was not smooth on the amalgamation of northern and southern protectorate in 1914; the Nigeria sub-national government and colony of Lagos enjoyed complete fiscal independence. The unified fiscal system was in place while a centralized budgeting system was introduced in 1926 before the amalgamation. However, the regionalism of 1946 evolved a decentralized fiscal structure. The Phillipson Commission of 1946 came as the first revenue commission, and quasi-federal structure of 1951 followed by selfgovernment from various regions in 1954. In the colonial era, four revenue commissions of HicksPhillipson commission (1951) and Chicks commission (1954) were established. Hicks-Phillipson recommends principles of derivation, even development and continuity of government services among the regions, need and national interest as revenue sharing principles (I ke, 1981).

Post-Independence/Military Period: The emergence of mid-western region brought the nation into four regions; in 1967 twelve states were created from the existing regions. In 1976 Nigeria has 19 states; 1987 additional two states were created thus bring the total to twenty one states, in 1991 the number rose to thirty states and Abuja. Since October 1996 till date, we have 36 states with 774 local councils. The Binns (1964), Aboyade (1977) and Okigbo (1979) commissions failed to give acceptable formula to Nigeria (Ozon-Eson, 2005).

Post-Democratic Era: The inception of democracy in 1999 brought civil authority to power; the central government was accused by oil states of not adhering to derivation principles as enshrined in the 1999 constitution of Nigeria. The onshore-offshore dichotomy states that oil found in the sea cannot be ascribed to the adjoining state; invariably this was done to reduce huge revenue allocation to oil producing states by the Obasanjo government. The controversy surrounding the onshore-offshore dichotomy is a clarion call for oil states to agitate for "resource control" from oil proceeds; these culminated in some states suing the federal government. The Revenue Mobilization and Fiscal Commission (RMAFC) inaugurated in 1999 were effective because Mr. President with federal Ministry of Finance were barred from interfering in revenue sharing. In 2004, the Federal Ministry of Finance in a letter to the Commission requested 54.68 percent for central government and they ignored their request for non-compliance with the provisions of section 164(1), 1999 constitution. The call for sub-national units and the central government to have more decentralized 
fiscal arrangement fell on deaf ears, fiscal commissions appointed by central government and national assembly formulate revenue principles centered on fiscal centralism, even when federal government attempted not to respect those formulas. The long incursion of the military into politics contributed to centrist fiscal federalism in Nigeria and this has distorted true federalism.

\section{Issues of Fiscal Federalism during Obasanjo Administration in Nigeria}

i. Resource control: The controversy between the Nigeria government and nine oil producing states of Akwa-Ibom, Cross River, Rivers, Bayelsa, Delta, Edo, Ondo, Abia and Imo states agitating for resource control in Nigeria, ranks as one of the major issues (Sanyaolu and Dunmoye, 2004). The federal government contended that the southern seaward states were inland waters within the state; the natural resource located within the continental shelf of Nigeria was in contention. All the oil states claimed that their territory extended beyond the low water mark on territorial waters and the exclusive economic zone. The natural resources derived from both onshore-offshore are national security irrespective of their territory and thereof entitled to 13 percent derivation formula set aside for oil states as provided in section 162, 1999 Constitution (Supreme Court, 5 April 2002). The issue of resource control has been a subject of controversy since 1999 till date, even the unanimous judgment of the Supreme Court could not put it to rest.

ii. Non-Correspondence Problem: Ideally, each level of government should have adequate resources to enable it discharge its responsibilities, and this is impossible due to noncorrespondence between the spending responsibilities and revenue sources to different levels of government. In Nigeria, most of the revenue sources fall within the jurisdiction of central government. The problems of fiscal federalism remain unresolved as divergence between assigned functions and tax powers (horizontal and vertical allocation), overdependence on the Federation Account makes federal presence unfelt in Nigeria (Fadahunsi, 1998). Federalism has the notion of unified national wage structure for federal, state civil servants and educational institutions, the component unit should establish salary structure based on capabilities (Okpe, 2005). In vertical formula, central government share should be reduced to 10 percent, state government 55 percent and local government 30 percent. On horizontal formula, equality ratios 40 percent, financial efficiency 10 percent, financial responsibility 10 percent, education and health 10 percent, derivation 20 percent and population 10 percent (Ekong, 2003).

iii. State and Local Government Joint Account: There is unbridled diversion of local government funds by state governors to the extent that hardly can any local government impact positively on its people after payment of staff salaries and personnel emoluments. In this arrangement, state government is the clearing house for councils' share from the federation account. Instead of state governments adding the mandatory 10 percent of internally generated revenue to local governments' they siphon resources allocated to them from the federal level. This situation worries the former chairman of Peoples' Democratic Party (PDP) Chief Audu Ogbeh, who threatened to deal with those governors with the penchant for deducting council funds and passing pittance to the localities (Ola, 2004:1). Despite this threat, the situation is unabated, and the worrisome is the continued denial by council chairmen of this fact, in the face of obvious evidence. This can be attributed to what most of these governors need from the chairmen, total loyalty to the governors who helped to put them in position, and this is so in that everywhere the last local council election was everything but credible. The diversion of local government funds has serious negative effects in Nigeria, on grass root development.

iv. Fiscal Dependence: The oil boom makes the state and local levels dependent on the Federation Account for revenue resources. In Nigeria, fiscal laws allocate more powers to federal level, while sub-national government lacks financial autonomy in their areas of 
jurisdiction. This has distorted constitutional mechanism to address problems of fiscal management. The inception of democracy in 1999 improved the situation. Barkan, et.al. (2001) states that local governments in Ogun, Nasarawa, Delta and Rivers states provide complete financial autonomy, the contract approval comes from the approval of local council legislative arm of their annual budget process. Military intervention weakened the revenue base to state and local levels due to the penchant for state creation and overdependence on crude oil (Akpan, 1999:218).

v. Revenue Sharing: The current revenue formula allocates more funds to central government at the expanse of states and local levels. The system has killed the urge for internally generated revenue (IGR). Even when the monthly allocations to councils come, it is reallocated by States Joint Allocation Committees (JACs). Agba and Bello-Imam (2004), assert mutual suspicion between the component groups on revenue allocation, the shift from resource control manifested arguments for and against derivation principle and other principles. Odoko and Nnanna (2009), state that fiscal federalism is anchored on who gets what, when and how of national cake. Akindele (2009) states that by virtue of constitutional provision, revenue should be disbursed to three tiers of government directly, but federal level has not justified its lion share with small expenditure assignment to component states (Nasir, 2011).

The literature reveals that fiscal federalism expenditure must be in the same level with taxation to reduce over-dependence in financing expenditures. Some challenging issues bordering on fiscal dependence, state local government joint account, resource control, non correspondence and revenue sharing formula inhibit national development from pre-colonial era to postindependence era in Nigeria.

\section{Theoretical Framework}

The Theoretical framework for the paper is "System Relations Approach to Inter-governmental Relation (IGR)" as propounded by Chin (1969), and cited in Olugbemi (1980). The systems model provides a comprehensive framework for identifying, coping with and integrating the institutional, behavioral and management dimensions of IGR. Furthermore, the systems model has a potential for resolving the allocation controversies which bedevil inter jurisdictional relationships. The theory is conceived as an organized purposeful whole, composed of structurally and functionally identifiable though inter-related parts and delineated by identifiable boundaries from the suprasystem (environment) in which it is embedded. Ackoff (1972) states that the emergence of systems construct marked an important transition from the mechanistic conception of social reality which sought to explain a phenomenon from the stand point of its component units to holistic view parts in terms of a whole. He sees a system as a whole which cannot be taken apart without the loss of its essential characteristics which include:

i. A set objective which the entity seeks to achieve, without which it cannot exist.

ii. A hierarchy of inter-dependent units among which the system objectives are divided for national development.

iii. Specificity of sub system roles, each system has a defined and specialized role in the realization of the total purpose(s) of the unitary whole and sub-system roles are mutually reinforcing.

iv. An input transforming technology which refers to the processes and techniques by which resource inputs extracted from within and outside the system are transformed into outputs which themselves have implications for system persistence and effectiveness through feed-back mechanism.

v. A boundary that excludes the plethora of other systems and defines the threshold of transactions among the universe of systems. 


\section{The Challenges of Fiscal Federalism during Obasanjo administration}

The agitation for resource control and recent clamour for new revenue sharing formula bequeaths more to the states and reduces that of the central government. Ozo-Eson (2005:20), states that Fiscal federalism issue must resolved if Nigeria is to continue as a federation for "true federalism". It is an established fact that the manner of revenue generation and distribution in a federal structure is critical to the sustenance of such relationship (Onuoha, 2007:76). Indeed, Nigeria's fiscal federalism emanated from geographical, historical, political, economic, cultural as well as social factors; the basic point has remained that in all fiscal arrangement that can guarantee peaceful co-existence has remained a mirage. Uche and Uche (2004) state that the main reasons for the amalgamation of Northern and Southern Nigeria in 1914 by the Colonial Government was to enable the Colonial Government reduce its subsidy on the Colony of Northern Nigeria by using the surpluses from Southern Nigeria. Irrespective of the formula in use, before the 1914 amalgamation of Nigeria, the principle of derivation was in vogue as each of the regions collected revenues of its internal resources mainly from agricultural, cash or export crops, taxation on import and export duties (Nwokedi, 2005:24). Egwaikhide (2001), state that the federal government takes "lion share" of the vertical allocation to itself and delegate more constitutional functions to the states. In the last fourteen (14) years of democracy, the nation has not been able to work out a revenue formula that complies with section 16 (2) of the 1999 Constitution that empowers the RMAFC to determine the mode of distributing the nation's wealth. Obasanjo then arrived at a formula that gave the Federal Government, 54.68 percent, states 24.72 percent and the Local Governments, 20.60 percent. Two years later, Dr. Ngozi Okonjo-Iwuala, modified the executive order by raising state allocation by two percent to 26.72 percent. The two percent was taken from the federal government's share bringing its own down to 52.68 percent. However, political observers believe that the lion's share of the national revenue given to the federal government runs against the grains of the current global trend in federalism, vis-a-vis, fiscal federalism. Against this background, there is a clamour for the return of "true federalism" thwarted in 1967 with the creation of 12 states. In addition, the high percentage of federal government's share of the revenue caused corruption, alienation, marginalization, instability and reckless agitation for restructuring in the country (Ugwu et al 2012:83).

\section{The practice of fiscal federalism and poor national development in Nigeria during Obasanjo administration}

Watts (1970) argues that federal finance is an important subject as it affects the allocation of administrative responsibilities, because the financial resources available will place limits on the scope of administration, which either level of government is able to sustain. Secondly, it affects the political balance because, whichever level of government has the major financial resources, finds in its hand the means of political control, third it is significant because, the assignment of fiscal and expenditure powers will determine which governments are able to use these instruments to control the economy (Watts, 1970). An important finding of the study is that the fiscal practice in Nigeria lacks equity and fairness as epitomized by the incessant manipulation of revenue allocation criteria and tax policies by the political class. The federal government in its attempt to provide some social services nationwide assumes more responsibilities than would ordinarily be the case under a Federal Constitution. Example of these include, provision of shelter, roads, transportation facilities, water supply amongst others, inevitably the functional responsibilities outweigh the available resources in line with statutory allocation from the Federation Account. Hence, the stringent measures taken by the federal government to cope with the situation include the use of dedication accounts, stabilization funds, petroleum special trust fund which substantially reduces the statutory allocations for state and local governments. The overall impact is that fiscal federalism has not been able to Reform optimally to national development. Adebayo (2002) noted that the internally 
generated revenue of the states and local governments, the statutory allocations from the federation account are not enough to match the responsibilities of these tiers of government. The oil producing states feel greatly marginalized as most of the resources from oil proceeds are to the central authority and few percentages are given to host communities. The internally generated revenue of the oil producing states could not attend to their development needs, and this situation applies to other states. The high concentration of federal wealth to central government has bogged down national development in Nigeria. Table 1 below shows the Summary distribution table of federal allocation to various tiers of government federal state and local government from the period of 1999 to 2007.

\begin{tabular}{|c|c|c|c|c|}
\hline & Beneficiary & State Government. & Local Government & $\begin{array}{c}\text { Total } \\
\end{array}$ \\
\hline 1 & Abia & $113,956,322,728.62$ & $66,957,033,320.83$ & $180,913,356,049.45$ \\
\hline 2 & Adamawa & $111,973,469,608.66$ & $88,385,118,660.50$ & $200,358,588,269.16$ \\
\hline 3 & Akwa Ibom & $384,370,238,540.34$ & $110,896,366,303.24$ & $495,266,604,843.58$ \\
\hline 4 & Anambra & $97,592,169,763.11$ & $85,847,453,591.19$ & $183,439,623,354.30$ \\
\hline 5 & Bauchi & $128,248,345,518.84$ & $98,833,751,081.01$ & $227,082,096,536.85$ \\
\hline 6 & Bayelsa & $414,158,710,867.12$ & $38,101,830,075.82$ & $452,260,540,942.94$ \\
\hline 7 & Benue & $120,963,431,284.39$ & $100,676,342,004.41$ & $221,639,773,288.79$ \\
\hline 8 & Borno & $127,814,189,455.35$ & $114,329,322,081.28$ & $242,143,511,536.62$ \\
\hline 9 & Cross River & $115,403,682,833.25$ & $74,990,493,054.89$ & $190,394,175,888.13$ \\
\hline 10 & Delta & $463,459,893,918.76$ & $97,961,571,804.08$ & $561,421,465,722.84$ \\
\hline 11 & Ebonyi & $97,825,886,665.52$ & $51,780,333,382.06$ & $149,606,220,047.59$ \\
\hline 12 & Edo & $119,085,051,909.31$ & $77,565,785,400.62$ & $196,650,837,309.93$ \\
\hline 13 & Ekiti & ,109.79 & $60,134,21$ & $152,866,276,435.50$ \\
\hline 14 & Enugu & $3,787.19$ & $68,964,491,966.13$ & $172,943,975,753.31$ \\
\hline 15 & Gombe & 6.74 & $49,916,381,357.36$ & $146,500,259,934.10$ \\
\hline 16 & Imo & 43.39 & 99,280 & $231,384,556,606.10$ \\
\hline 17 & Jigawa & $117,009,31$ & $108,615,763,243.89$ & $225,625,079,684.13$ \\
\hline 18 & Kaduna & $138,928,609,161.09$ & $117,182,125,094.69$ & $256,110,734,225.77$ \\
\hline 19 & Kano & $179,437,799,067.94$ & $191,497,373,448.88$ & $370,935,172,516.81$ \\
\hline 20 & Katsina & $140,721,433,816.83$ & $139,822,729,992.43$ & $280,544,163,809.26$ \\
\hline 21 & Kebbi & $109,325,901,797.25$ & $86,787,009,340.22$ & $196,139,911,137.47$ \\
\hline 22 & Kogi & $108,937,683,153.98$ & $86,187,515,182.33$ & $195,125,198,336.31$ \\
\hline 23 & Kwara & $99,576,991,214.56$ & $66,011,107,696.79$ & $165,588,098,911.35$ \\
\hline 24 & Lagos & $182,535,977,642.02$ & $149,392,517,393.59$ & $331,928,495,035.61$ \\
\hline 25 & Nassarawa & $90,518,301,030.98$ & $54,487,876,090.81$ & $145,006,177,121.79$ \\
\hline 26 & Niger & $126,254,889,591.23$ & $111,114,801,956.06$ & $237,369,691,547.30$ \\
\hline 27 & Ogun & $114,180,594,528.10$ & $81,197,512,355.95$ & $195,378,106,884.06$ \\
\hline 28 & Ondo & $183,313,507,542.89$ & $74,082,244,267.18$ & $257,395,751,810.07$ \\
\hline 29 & Osun & $107,476,926,982.08$ & $102,574,611,292.67$ & $210,051,538,274.76$ \\
\hline 30 & Oyo & $135,928,952,381.15$ & $127,369,093,326.38$ & $263,298,045,707.53$ \\
\hline 31 & Platueau & $81,759,592,808.53$ & $73,434,508,057.07$ & $155,194,100,865.61$ \\
\hline 32 & Rivers & $517,682,993,860.57$ & $104,313,280,579.65$ & $621,996,274,440.22$ \\
\hline 33 & Sokoto & $118,067,536,171.07$ & $96,232,809,149.69$ & $214,300,345,320.76$ \\
\hline 34 & Taraba & $103,462,234,004.51$ & $72,869,810,839.60$ & $176,332,044,844.11$ \\
\hline 35 & Yobe & $104,904,723,192.25$ & $72,326,009,351.84$ & $177,230,732,544.09$ \\
\hline 36 & Zamfara & $112,898,217,046.50$ & $70,091,324,490.36$ & $182,989,541,536.86$ \\
\hline \multirow[t]{2}{*}{37} & FCT & $149,703,394,069.21$ & $43,324,238,682.88$ & $193,027,632,752.09$ \\
\hline & Total & $5,742,903,843,313.33$ & $3,313,534,856,541.80$ & $9,056,438,699,855.13$ \\
\hline \multirow[t]{2}{*}{38} & Fed Govt & & & $7,390,688,951,768.72$ \\
\hline & Grand Total & & & $16,447,127,651,623.80$ \\
\hline
\end{tabular}

Source: Federal Ministry of Finance 2007 
Despite that the federal government kept about N7,390,688, 951,768.72, state received $\mathrm{N} 5,742,903843313.33$ and local government received $\mathrm{N} 3,313,534,541.80$ from the federation account within the periods of 1999 to 2007 financial years to provide service delivery to Nigerians, their performance remain poor (Eboh and Igbokwe, 2006). Public resources have been poorly managed, characterized with frivolous activities, leaving little for essential services. The provision of services is increasingly available mostly in the affluent areas and the quality of services is highly variable, and the cost recovery within the sector is increasing and individuals that pay for such services are poor.

\section{Discussion}

The fiscal federalism practice in Nigeria reveals that the central authority has the lion share of the national cake. The states and local governments are denied adequate funds to take care of their responsibilities. The budgetary allocation from 1999 to 2007 reveals that Nigeria is currently running an un-federal fiscal federalism and the South-South geo-political zone is indeed marginalized. Ailoje (2001) observes that the reliance of the revenue allocation formula on population and land mass does not favour South-South and South East, relative to other zones of the country. Edevbie (2003) noted that the Southern states which generate $90 \%$ of the nation's revenue are supposed to receive more allocation; instead they receive one tenth of its contribution. The issue of resource allocation have triggered of many actions, especially among the sub-national governments that complain of fiscal imbalance (Okoro, 2006). In addition, the federal government went ahead to treat external debt service as a first line charge on oil revenue. With all these the country cannot experience national development, when there are no resources at the disposal of sub-units in Nigeria, the oil producing states are left with nothing. In line with our analysis, we conclude that the problem of national development has been as a result of imbalance in fiscal federalism among the three levels of government (federal, state and local).

\section{Conclusion and Recommendations}

The paper focused on fiscal federalism and national development, in relation to Nigeria from 1999 to 2007. The outcome of the hypotheses clearly states that Nigerian political leaders have not demonstrated genuine willingness to address the challenging issues that have incapacitated national development between 1999 and 2007.The non-implementation of the constitutional provisions has not addressed the problem of efficient revenue allocation formula, resource control, state and local government joint account, fiscal dependence and non correspondence as a feature of fiscal federalism. The nature of fiscal federalism has not addressed national development in Nigeria. Based on the outcome of this the following recommendations were made to proffer solutions to the undesirable effects of defective fiscal federalism and national development in Nigeria.

i. The lopsidedness in the revenue allocation formula which gives $50 \%$ revenue to federal, $35 \%$ to states and $15 \%$ to local council should be restructured in favour of states and local government to increase their capacity towards national development in their respective administrative units.

ii. Since the states and local council are the federating units in a federation, at least $60 \%$ of the revenue should be shared between these two tiers in a ratio to be determined by all relevant stakeholders to be more responsive to people's need.

iii. There is need to strengthen the fiscal base of sub-national governments, by assigning more revenue heads and eliminating non performing tax heads from their revenue collection.

iv. The sub-national government must strive towards more effective and efficient collection of sources of revenue generation to plug of all leakages in the IGR collection and utilization 
process.

v. Finally, the persistent agitation for resource control by the oil- producing states need to be addressed not just the increase on quantum of money accruable to them, but through building up of the capacity of their youths to engage or participate in the oil- extraction process in their region.

\section{References}

Ackoff, R. (1972): On Purposeful Systems: An Interdisciplinary Analysis of Individual and Social Behavior as a System of Purposeful Events. Atherton: Chicago.

Adebayo, A. (2004): Revenue Allocation: A Historical Analysis of the Nigerian Experience. Lagos: Longman.

Agba, A. and Bello-Imam, I. (2004); "Fiscal Federalism, The National Question and Resources Control: Practice and Prospect" in Democratic Governance \& Development Management in Nigeria's Fourth Republic, 1999-2003, Bello-Imam, I. \& Mike O. (eds.), I badan: JODAD Publishers.

Chin, R. (1969): The Utility of System Models and Developmental Models for Practitioners. New York: Winston Inc.

Egwaikhinde, F. and Mbanefo, G. (1998): "Revenue Allocation in Nigeria: Derivation Principle" Revisited in Amuwo et.al (eds.) Federalism and Political Restructuring in Nigeria. Ibadan: Spectrum Books Ltd.

Ekong, A. (2003): "Renewing the Federal Paradigm in Nigeria: Contending Issues and Perspectives" in Federalism in Africa. Gama, A. and Egwu, S. (eds.) Asmara: Africa World Press, Inc.

Fadahunsi, A. (2005): Nigerian beyond Structural Adjustment. Lagos: Panaf Pub. Inc.

I sumonah, A. (2001): Intergovernmental Fiscal Relation in Nigeria. Ibadan: PEFS

Musgrave, R. (1959): The Theory of Public Finance. New York: McGraw-Hill.

Nwokedi, R. (2005): Power Sharing in Nigerian Federation: special National political Reform Conference Edition. Enugu: Snaap Press Ltd.

Nworgu, B. (2006): Educational Research: Basic Issues and Methodology $2^{\text {nd }}$ (ed.). Enugu: University Trust Publishers.

Odoko, F. and Nnanna, F. (2009): Fiscal Federalism: Fiscal Discipline and Service Delivery in Nigeria. Enugu: Snaap Ltd.

Okoli, F. and Onah, F. (2002): Public Administration in Nigeria: Nature, Principles and Application. Enugu: J ohn Jacob Publishers.

Okpe, O (2003): The Sovereign National Conference: Issues, Perspectives and Challenges. Makurdi: Aboki Publishers.

Olalokun, F. (1980): “Nigeria Federal Finance: Issues and Choice” in Akinyemi, C. and Ofonagoro (eds.): Readings of Federalism .Third Press International $2^{\text {nd }}$ Edition.

Onah, F.E. (2006): Fiscal Federalism in Nigeria. Nsukka: Great AP Publishers LTD

Onuoha, J. (2007): Theory and Practice of Intergovernmental relations in Nigeria. Enugu: Quintagon Publishers.

Suberu, R. (2001): Nigerian Federalism in Crises: Critical Perspectives and political Options. I badan: John Archers Publishers.

Talja, S. (1997): "Constituting Information and Users as Research Objects: A Theory of Knowledge Formations as an Alternative to the Information Man-Theory" in Pertti Vakkari, Reijo Sarolainen and Beranda Dervin (eds.) I nformation Seeking in Context. London: Taylor Graham.

Teidi, S. (2003): Federalism and Inter-governmental Fiscal Relations in Nigeria. Ibadan: Spectrum Books Ltd.

Tekun, T. (2000): Federalism and Political Restructuring. Ibadan: Spectrum Books Ltd.

Uche, U. (2004): "Oil and Politics of Revenue Allocation in Nigeria" Leiden: African Studies Centre.

Watts, R. (1970): Administration in Federal Systems. London: Hutchinson Educational Ltd.

Wheare, K.C (1963): Federal Government. New York: Oxford University Press.

Woodhall, M. (1985): Education for National Development: An Analysis of Investment Choices. London. Oxford University Press. 


\section{Journals}

Adeleke, S. (2011): “Taxation, Revenue Allocation and Fiscal Federalism in Nigeria: Issues, Challenges and Policy Options" Economic Annals, Vol. LVI, (189). Pp 120-130.

Aigbepue, S. and Ainabor A. (2011): "Issues and Challenges of Nigerian Fiscal Federalism" Interdisciplinary Journal of Research in Business Vol. 1, (10), Pp.26- 31

Akpan, E. (2011): "Fiscal Decentralization and Social Outcomes in Nigeria European Journal of Business and Management $\mathrm{Vol}$ 3, (4), Pp. 167-183

Arowolo, D. (2011): "Fiscal Federalism in Nigeria, theory and Dimensions" Afro Asian Journal of Social Sciences Vol. 2, (2). Pp. 5-21

Danjuma, T. (1994): "Revenue Sharing and the Political Economy of Nigerian Federalism". Journal of Federalism 1(1): 43-68.

Ekpo, A. (2003): "Fiscal federalism: Nigeria Post-Independence experience" 1960-90, World Development Vol. 22, (8), 65-71

Elaigwu, J. (2000): "Federalism, Institutional and Political Stability in the Context of Vision 2010" African Journal of Federal Studies. Vol.1 (1) Pp.34-64.

Ike, D. (1981): "Towards an Optimal Formula for Revenue Allocation in Nigeria" Nigerian Journal of Development Studies, 1 (2), 104-109.

Naomi, O. (1995): "Towards an Integrated View of Human Rights". Hunger Teach Net, 6(3): 6-7.

Nyong, M. (1999): "Fiscal Federalism, Revenue Allocation Formula and Economic Development in Nigeria" Nigerian Financial Review. 7 (3). PP. 33-37

Oates, W. (1999): "An Essay on Fiscal federalism" American Journal of Economic Literature, 37(3):112049.

Olugbemi, S.O. (1980): "A System Approach to Intergovernmental Relations" A Quarterly Journal of Administration, OAU Ile-Ife 14 (2) Pp.162-163.

Owolabi, U (2011): "Fiscal Federalism and Economic Growth Process in Nigeria" European Journal of Business and Management $\mathrm{Vol}$ 3, (4), 1-11

Sanyaolu, K and Dumonye, C. (2002): "Resource Control: Which Way Forward" The Nigerian Social Scientists 5, 49-53.

Tiebout, C. (1956): "A Pure Theory of Local Expenditure" Journal of Political Economy 64, 416-424.

Tolu, L. and Abe, O. (2011): National Development in Nigeria: Issues, Challenges and Prospects. Journal of Public Administration and Policy Research Vol. 3(9), Pp. 237-241.

Ugwu, C. et. al (2012): "Issues in Nigeria Fiscal Federalism; The Relationship between the Principle of Derivation and Resource Control". Kuwait Chapter of Arabian Journal of Business and Management Review Vol. 1, No.5, Pp. 78-91.

\section{Newspapers and Magazines}

Nasir, A. (2011): "True fiscal federalism is the Answer" The Nation, Friday August 19, 20-21

Ozo-Eson, P. (2007): "Fiscal Federalism: Theory, Issues and Perspectives". Daily Independent 29, Pp. 2021.

Sagay, I. (2008). "How a True Federal System Should Run". The Nation, Lagos, May 19, Pp.18-20.

Supreme Court Verdict (2002) "States Lose Resource Control Suit Supreme Court Favors Federal Government" The Guardian: April 5, Pp 14-20.

Taiwo, T. (2000) "Citizen and Citizenship" Post Express: March 1, Pp 34-35.

Yusuf, A. (2012): "States Battle Federal Government over Excess Crude Cash" Thisday, March 17, pp. 1213

\section{Internet and Other Electronic Sources}

Barkan, J. et al. (2001): "State and Local Governance in Nigeria" Public Sector and Capacity Building Program, Africa Region. World Bank.http://info.worldbank.org/etools/docs/library/5783 /State_and_Governance_Nigeria.htm

Buettner, T. and Wildāsin, D. (2007). "A New Directions in Fiscal Federalism" 
http://cesifo.oxfordjournals.org/cgi/content/extract

Denila, M. (2002): "True Federalism and Resource Control" http://nigeriaworld.com/articles/2005 /jul/073.html

Ifurueze, M. et al (2012): "Fiscal Federalism and the Issue of Resource Control in Nigeria: The Challenges, Options \& Strategies" http://www.eurojournals.com/EJEFAS.htm

Ikeji, C. (2011): "Federalism and Revenue Allocation in Nigeria: Theory, Practice and Dynamics" www. sachajournals.com

Mobolaji, E.(2002): "The Federal Government suit over Resources Control" Mid week essay. http://www.und.Ac.29.

Omotoso, F. (2003): "Administrative Problems of State Creation in Ekiti State, Nigeria"< http://www.academicjournals.org/AJPSIR>

Wikipedia (2010): http://wiki.answers.com/_national_development

\section{Official Publications and Conferences Papers}

Aboyade C. (1977): "Report of the Revenue Allocation Committee" cited in Olowonomi, G (2000)

Akpan, G. (1999): "Fiscal Federalism and Nigeria's Economic Development" Proceedings of the 1999 Annual Conference of the Nigerian Economic Society, 73-100.

Binns Commission (1964): "Report of the Fiscal Commission" Lagos: Federal Government Press.

Federal Republic of Nigeria (1979): "Constitution of the Federal Republic of Nigeria". Lagos: Federal Government Press.

Federal Republic of Nigeria (1999): "Constitution of the Federal Republic of Nigeria" Lagos: Federal Government Press.

Gboyega, A. (2003): "Democracy and Development: The Imperative of Local Governance" An Inaugural Lecture, University of I badan.

Taiwo, I. (1999): "Fiscal Federalism: A Theoretical Framework" Paper Presented at the Annual Conference of the Nigerian Economic Society, 3-23.

Vincent, O. (2001). "Fiscal federalism: Nigerian Experience" Fourth Republic Lecture: The Nigerian Economic Society.

\section{Unpublished Work}

Akindele, O. (2009): "Local Government Tax Mobilization and Utilization in Nigeria", M.sc Seminar Presented to the Department of Public Administration, University of Maiduguri, 5th October.

Okeke, M. (2004) The Politics of Revenue Allocation and Resource Control in Nigeria: A Critical Analysis of the Niger Delta Crises. A Seminar paper Presented at the Department of Public Administration, University of Nigeria, Nsukka for Ph.D. 